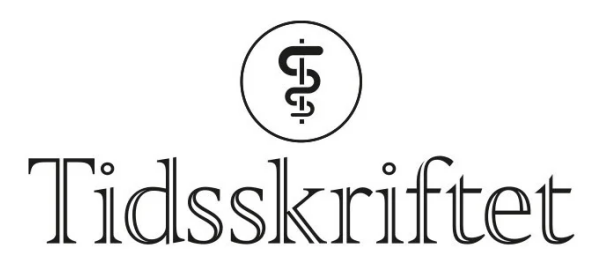

DEN NORSKE LEGEFORENING

\title{
Vi er kjent med problemstillingen
}

\author{
KOMMENTAR
}

METTE FAGERNES

mette.fagernes@fhi.no

Mette Fagernes er seniorrådgiver ved Avdeling for smittevern og beredskap, Folkehelseinstituttet. Forfatteren har ikke oppgitt noen interessekonflikter.

Takk til Arnstein Fedøy for fin artikkel i Tidsskriftets utgave 9(1), som løfter frem en viktig problemstilling. Dette er relevant både for helsetjenesten, og for andre sektorer som tradisjonelt ikke benytter denne type produkter, men som nå i forbindelse med covid19 pandemien har et stort forbruk av alkoholbaserte hånddesinfeksjonsmidler.

Vi er enige i budskapet ditt, dette er en problemstilling som fortjener mer oppmerksomhet, også på Folkehelseinstituttets sider. Det medfører imidlertid ikke riktighet at Folkehelseinstituttet påstår at utplassering av dispensere verken er risiko- eller brannproblematisk. Tvert imot. Dette er en problemstilling vi er kjent med og opptatt av. Vi henviser i teksten til at det i Norge, i motsetning til i andre land ikke finnes detaljerte krav til plasseringen av den enkelte dispenser, men at plassering må gjennomgås med sikkerhetsansvarlig ved den enkelte enhet for å sikre at nødvendige forhåndsregler blir tatt. Øvrig regelverk omtales som du nevner ikke.

Den nasjonale veilederen for håndhygiene er fra 2016 og skal revideres høsten 2021. Vi vil se på behovet for å tydeliggjøre risiko knyttet til oppbevaring av alkoholbasert

hånddesinfeksjonsmidler, og regelverket rundt dette. Vi vil også se på behov for presisering i artiklene vi har ute om dette i koronaveilederen.

\section{LITTERATUR}

1. Fedøy A. Håndsprit er brannfarlig. Tidsskr Nor Legeforen 2021; 141. doi: 10.4045/tidsskr.21.0316. [PubMed][CrossRef]

Publisert: 16. august 2021. Tidsskr Nor Legeforen. DOI: 10.4045/tidsskr.21.0523

(C) Tidsskrift for Den norske legeforening 2023. Lastet ned fra tidsskriftet.no 26. april 2023. 